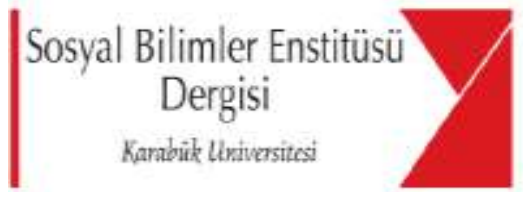

$\begin{array}{lr}\text { Yıl: } 2015 \\ \text { Cilt: } & 5 \\ \text { Sayı: } & 2\end{array}$

\title{
Korunan Alanların Turizme Açılmasına İlişkin Yerel Halkın Görüşleri (Yenice Örneği)
}

\author{
Fatih Türkmena*, Yasin Dönmez ${ }^{\mathrm{b}}$ \\ ${ }^{a}$ Karabük Üniversitesi, Safranbolu Turizm Fakültesi, Karabük. \\ ${ }^{b}$ Karabük Üniversitesi, Orman Fakültesi, Karabük.
}

\begin{abstract}
Öz
Turizmin tarihsel gelişimi incelendiğinde, turistlerin destinasyon seçimi kadar, yerel halkın turizme bakış açısı da önemli konulardan birisi olmuştur. Özellikle kültür turizmine olan ilginin artmasıyla, korunan alanlarda sürdürülebilir turizm anlayışının geliştiği bilinmektedir. Dolayısıyla koruma altına alınmış bir alanı, ekonomik açıdan gelişime açı bir turizm ürünü olarak tanıtırken, yerel halkın da desteğini göz ardı etmemek gerekmektedir. Bunu yaparken hem koruma altındaki çevreyi korumak hem de yerel halkının ve ziyaretçilerin ihtiyaçlarını karşılamayı başarmış olmak, bu alanların dengesini bozmadan gelişimi açısından oldukça önemlidir. Bir bölgenin sahip olduğu turistik değerlerin potansiyeli ne kadar yüksek olursa olsun, bölge halkının desteği ve izni olmadan turizmin geliştirilmesi çok zordur. Bu amaçla çalışmada, korunan bir alan olarak Yenice'nin turizme yönelik gelişiminde yerel halkın turizme bakış açısı ekonomik, sosyo-kültürel ve çeoresel etkenlere göre değerlendirilmiştir. Anket yöntemiyle 698 örneklem üzerinden elde edilen veriler parametrik olmayan Mann-Whitney U Testi ve Kruskal-Wallis $H$ Testi ile analiz edilmiştir. Yapılan analizler neticesinde katılımclların; cinsiyetlerine, medeni durumlarına, yaşlarına, eğitim durumlarına, ilçedeki yaşam sürelerine, gelirlerine ve mesleklerine göre anlaml farkliliklar bulunmuştur.
\end{abstract}

Anahtar Kelimeler: Korunan Alanlarda Turizm, Yerli Halkın Turizm Algısı, Yenice.

\section{Residents' Perception towards Opening the Protected Areas to Tourism (The Case of Yenice)}

\begin{abstract}
When the historical development of tourism is analyzed, it can be seen that local people's perceptions has been one of the curicial issues as the choice of destination for tourists. Especially by the increased interest in cultural tourism, sustainable tourismconcept in protected areas has increased. While promoting a protected area as a tourism product which is open for improvement in economic aspect, the local people's support should not be ignored. In doing so, both preserving the protected area and meeting the needs of local people and visitors are important for the development of the area without degredation. No matter how high the potential of touristic attractions in the area, development of tourism without support of the local people is very difficult. For this purpose, in development of tourism in Yenice, a protected area, perceptions of local people towards tourism are analyzed in the context of economic, socio-cultural, and environmental impacts. Data obtained from 698 residents using a questionnaire form are analyzed using nonparametric Mann-Whitney $U$ and Kruskal-Wallis $H$ test. Results show that there are significant differences between the gender, marital status, age, education status, length of residency, income, profession and the tourism impacts.
\end{abstract}

Key words: Tourism in protected areas, Resident perceptions towards tourism, Yenice

*Yazışma adresi. Email: fatihturkmen@karabuk.edu.tr 


\section{GİRiş}

Dünyadaki korunan alanlar, nüfus artışı, toplumsal gelir düzeylerinin artması, yanlış ve aşırı kullanım ve endüstrileşme ile birlikte büyük bir tehditle karşı karşıyadır. Bu tehditlerin başında doğal yaşam ortamlarının bozulması biyolojik çeşitliliğin azalması ve sürdürülebilirliğin sağlanamaması gelmektedir. Ayrıca gerçekleştirilen birçok araştırma sonucunda yapılan tahminlerde geçmişte olduğundan daha fazla bir hızla canlı türlerinin kaybolma tehlikesi bulunduğu sanılmaktadır (Hepcan, 1995; Yüksek ve ark., 2008; Akten ve ark., 2009; Alptekin ve ark., 2010; Güneş, 2011). Bu ve benzeri belli başlı tehditlerle mücadelede, doğal ve kültürel kaynakların korunmasında, biyolojik çeşitliliğin sürdürülmesinde orman kaynaklarının ürettiği hizmetler ve ormancılık etkinlikleri önemli bir rol oynamaktadır (Hepcan ve Güney, 1996). Bu çerçevede ormancılık etkinlikleri ile birlikte korunan alanların varlığı ve yönetimi de giderek daha kritik bir işleve sahip olmaktadir.

Günümüzde korunan alanlar uluslararası ve ulusal doğa koruma çabalarının en önemli unsurlarından biridir. Yasal-yönetsel araçlar ve insan kullanımlarına getirilen sınırlamalar sayesinde bu alanlar doğal ve kültürel kaynakların, biyolojik çeşitliliğin korunmasında yaşamsal işlev görmektedir. Dolayısıyla korunan alanlar çevresel-ekolojik, sosyo-ekonomik ve kültürel işlevlerini ancak etkili bir şekilde yönetildiklerinde yerine getirebilir. $\mathrm{Bu}$ çerçevede yaşamsal işlevlerinin korunmasının en etkili yolunun, ulusal düzeyde bir korunan alan sisteminin oluşturulması ve bu sistemin etkin yönetiminden geçeceği görülmektedir (Akesen, 1984; Ekizoğlu ve Kuvan, 2010).

Sarıçam (2007)'a göre; 1990'lı yıllara kadar doğa koruma yaklaşımları incelendiğinde, genelde doğa koruma alanlarının içinde ve/veya yakın çevresinde yaşayan yerel halkın sistem dişında tutulduğu görülmektedir. Ancak yerel toplulukların korunan alan yönetimine katılımına ilişkin ulusal ve uluslararası gelişmelerin bir sonucu olarak, son zamanlarda korunan alanların üzerinde yeni bir bakış açısına ihtiyaç duyulmuştur. Yerel toplulukların korunan alanların yönetim sürecine dahil edilmesinin ortaya çıkardığı yeni bakış açılarından biri, korunan alanların yönetimine getirilen bütünsel yaklaşımdır (Dönmez, 2013).

Butler (1980), “Turizm Alanı Yaşam Döngüsü" çalışmasında, turizm bölgelerinde yaşayan halkın başlangıçta turizmin ekonomik etkileri ve turiste olan sempati nedeniyle turizme karşı olumlu yaklaşımlar sergilediğini, zaman geçtikçe turizmin ekonomik, sosyal ve çevresel etkilerinin rahatsızlık verici duruma gelmesi nedeniyle gelişim sürecinin durağanlaşması ve gerilemesinin söz konusu olduğunu vurgulamıştır. Butler'a göre, turizmin gelişim sürecinde yerel halkın turizmin etkileri konusundaki algılarının önemli bir yeri vardır. Yerel halkın turizm üzerindeki asıl ilgi alanı, turizmin kişisel yaşam alanları üzerindeki etkileridir. Bir turizm gelişim stratejisinde yerli halkın turizme bakış açısı, sağlanacak yararlardan ya da kardan çok, turizmin ekonomik, sosyo-kültürel ve çevresel etkilerinin algılanmasına göre değişkenlik gösterir (Alaeddinoğlu, 2007). 
Gelenekselleşmiş sürdürülebilir turizm gelişimi anlayışında zaten turizmin ekonomik, sosyal ve çevresel etkilerinin irdelendiği bir dizi değerlendirme süreci vardır. Bu değerlendirme sürecinde halkın algısı ve tepkileri, sürdürülebilir turizm gelişimini yönlendiren önemli bir güçtür. Yapılan bazı çalışmalarda da, turizm gelişimi için yerel halkın desteğinin önemi vurgulanırken, yerel halkın turizme olumlu bakış açısının gelişimi hızlandıran bir nokta olduğu ifade edilmektedir. Turizm gelişimini etkileyen faktörlerden birisi olarak yerel halk ve yerel halkın turizme bakış açısı, sosyo-kültürel faktörler olarak değerlendirilmiştir. Bu değerlendirmeler aynı zamanda turizm bilincinin geliştirmesi gibi konularla da ilişkilendirilmiştir (Gümüş ve Özüpekçe, 2009; Kozak vd., 2010).

Günümüzde turizm sayesinde başta ABD olmak üzere Fransa, İspanya ve Yunanistan gibi Avrupa ülkeleri çok yüksek gelir elde etmektedirler. Turizmin bu ülkelerde gelişimi incelendiğinde, sahip olunan doğal ve kültürel özelliklerden başka buralarda yasayan yerel halkın turizme yaklaşımlarının çok önemli bir rol oynadığı görülmektedir. Türkiye sahip olduğu doğal ve kültürel değerleriyle turizm açısından gelişmiş olan ülkelerden çok daha fazla kaynaklara sahip olmasına rağmen, yerel halkın bu anlamda desteğini sağlayamadığı için turizmden elde edebileceğinden çok daha az bir gelir elde edebilmektedir. Yerel halkın turizmin gelişmesine katkı vermesini sağlamak için onların turizm gelişmesine karşı tutumlarının ve bu tutumları etkileyen faktörlerin belirlenmesi gerekmektedir (Cengiz ve Kırkbir, 2007).

Turizm araştırmacıları yerel halkın turizme desteğinin ekonomik, sosyal, kültürel ve çevresel sonuçlara göre şekilleneceği kanaatindedirler. Turizm sonucu oluşan etkilerin toplamina "algılanan toplam turizm etkisi" denilir. Toplam turizm etkisi de turizme olan desteği sekilendirir. Sosyal değişim teorisine göre yerel halk turizm sonucu istenmeyen ve kabullenilmeyecek maliyetlerin olmayacağına inandıkları takdirde turistlerle mübadelede bulunacaklardır. Başka bir deyişle yerel halk turizmin farklı etki alanlardaki sonuçlarının olumlu taraflarının olumsuz yönlerinden daha fazla olacağ fikrine sahip olurlarsa turizm gelişim sürecine dahil olacaklar ve turizme katkı sağlayacaklardır (Murphy, 1983; Liu vd., 1987; Perdue vd., 1990; Getz, 1994; McCool ve Martin, 1994).

Dünyada mevcut farklı özelliklere sahip korunan alanlar, turistlerin ilgilerini sürekli olarak çekmeye devam etmektedirler. Kültürel turizm kapsamında ziyaret edilen bu yerler, sahip oldukları doğal ve kültürel özelliklerden dolayı yılın tamamına yakın yerli ve yabancı turist akımına uğramaktadırlar. Bu bölgelerde yaşayan halkın gelir kaynakları yetersiz ve hatta bu yerleri bırakıp büyük kentlere göçmeleri yapılan araştırmalar neticesinde ortaya konulmuştur. Halbuki kırsal bölgelerde yaşayan halkın gelir seviyesini yükseltmek, bu alanların bozulmayacak şekilde turizme açılması ile sağlanmış olacaktır (Türker vd, 2013)

$\mathrm{Bu}$ çalışma da Karabük ili Yenice ilçesinin incelenmesindeki temel husus; Yenice ormanlarının sıradan orman alanları içinde olmaması, bununla beraber Gıda ve Tarım 
Örgütü (Food and Agriculture Organization)'nun dünya üzerinde belirlediği Mutlak Korunması gereken alanlar içinde100 adet sıcak nokta içerisinde yer alan Türkiye 'deki 9 adet ormandan biri olmasıdır (Türker ve Çetinkaya, 2009).

\section{MATERYAL VE YÖNTEM}

Karabük ilinin $33 \mathrm{~km}$ batısında yer alan Yenice, Yenice Irmağ1 ile İncedere ve Bakraz Dere'nin birleştiği noktada kurulmuştur. Yüz ölçümü 1150 km², deniz seviyesinden yüksekliği 112 m'dir. Batı Karadeniz iklim mıntıkası içinde yer alan Yenice ilçesi, nemli, yağışlı ve sisli bir iklime sahiptir. Yıllık ortalama sıcaklık $8.8^{\circ} \mathrm{C}$, yıllık ortalama yağış miktarı 1200 mm, yıllık ortalama nispi nem \% 76.2'dir. Bakir ormanlara sahip olan Yenice'de 115 bin hektarlık alanın \% 85'i (82.448 ha.) ormanlarla kaplıdır. Bu alanın 79.606.5 ha'1 koru, 2.841.5 ha'1 baltalık ormandır. Halkın \% 89 'unun geçim kaynağını ormancılık oluşturmaktadır. Yenice ormanları sıradan orman alanları değildir. Biyolojik çeşitlilik bakımından oldukça zengin bir yapıya sahiptir. Bunun nedeni Yenice ormanlarında tropik bölgeler dişında, dünyada pek az ormanda görülebilecek kadar çok sayıda ağaç, ağaççık, bitki ve yaban hayvanının bir arada yaşamasıdır. İlçe ormanlarında 33 ağaç çeşidi, 8 ağaççık çeşidi ve birçok otsu bitkinin yanı sıra 16 çeşit şifalı bitki de bulunmaktadır (Türker ve Çetinkaya, 2009). Dolayısıyla bu denli niteliklere sahip bir bölgenin turizme açılması noktasında yerel halkın görüşlerinin alınması ayrıca önemlidir. Çünkü turizmin olumlu etkileri yanında olumsuz etkilerinin olduğu da bilinmektedir ve bu durumdan en fazla düzeyde yerel halkın etkilenebileceği unutulmamalıdır.

\section{Evren ve Örneklem}

Korunan bir alan olan Yenice'de yerel halkın turizme hakkındaki görüşlerinin değerlendirildiği bu araştırmada; yerel halkın demografik özellikleri ile turizmin ekonomik, sosyo-kültürel ve çevresel etkenleri hakkındaki düşünceleri arasındaki farklılıklar incelenmeye çalışılmıştır. Dolayısıyla araştırmada "Yenice'de yaşayan yerel halkın turizmin ekonomik, sosyo-kültürel ve çevresel etkileri hakkındaki görüşleri demografik özelliklerine göre farklılık göstermekte midir?" sorusuna cevap aranmaya çalışılmıştır. 2015 yılı Mart-Temmuz ayları arasında yapılan araştırmanın evrenini oluşturan Yenice'de yaşayan yerel halkın özelliklerini temsil edebilecek örneklemin belirlenmesinde, kolayda örnekleme yöntemi kullanılarak ve örneklem büyüklüğü

$\mathrm{n}=\sigma^{2} \mathrm{Z}_{\mathrm{a}}^{2} / \mathrm{d} 2$ formülünden yararlanılarak (Özdamar, 2001) hesaplamalar yapılmış olup, katılımcıların görüşleri alınmıştır. Formülde standart sapma $\sigma=1$; evren ve örneklem ortalaması arasında izin verilebilir etki genişliği değeri $\mathrm{d}=0,10$; anlamlılık düzeyi $\alpha=0,05$ ve bu anlamlılık düzeyine karşılık gelen teorik değer Z0,05=1,96 olarak alınmış olup, örneklem büyüklüğü 385 olarak hesaplanmıştır. 


\section{Veri Toplam Yöntemi}

Anket tekniğinin uygulandığı bu çalışmadaki anket iki bölümden oluşturulmuştur. Birinci bölümde, demografik özellikleri belirleyebilmek adına sekiz soruya (cinsiyet, medeni durum, yaş, eğitim durumu, doğum yeri, ilçedeki yaşam süresi, gelir, meslek), sonraki bölümde ise araştırmacılar tarafından Teye, Sönmez ve Sirakaya (2002); Andriotis ve Vaughan (2003)'nın çalışmalarından ve ulusal literatürde bulunan konuyla ilgili diğer çalışmalardan yararlanılarak geliştirilen toplam otuzdört ifadeye yer verilmiştir. Araştırmada kullanılan ölçekler orijinal dillerinden uzman görüşleri alınarak Türkçeye çevrilmiş sonrasında tekrar Türkçeden orijinal dillerine çevrilmiş olup, böylece dil geçerliği ile faktör analizi yapılarak yapı geçerliğine tabi tutulmuştur. Bu kapsamda geçerlik ve güvenirliğine yönelik bulgular Tablo 1'de sunulmuştur. Aynı tabloda ölçeğin güvenirliği Cronbach's Alpha katsayılarına göre $\alpha=0,70$ 'in üzerinde olduğundan (Kayış, 2009)'a göre bu ölçeğin güvenilir olduğu söylenebilir. Bu ifadeler 5'li Likert Ölçeği'nde çoktan seçmeli (1-Hiç Katılmıyorum; 5-Tamamen Katılıyorum) şeklinde tasarlanmış olup, turizmin ekonomik, sosyo-kültürel ve çevresel etkenlerini yansıtacak biçimde oluşturulmuştur. Hazırlanan bu anket formu 1000 adet çoğaltılarak hedef kitle üzerinde uygulanmıştır. Uygulama sonrasında eksik ve geçersiz verilerden dolayı yapılan elemeden sonra 698 anket değerlendirmeye alınmıştır.

\section{Verilerin Analizi}

Elde edilen veriler SPSS 23 for Windows paket programı kullanılarak analiz edilmiş olup, ifadelerin faktör yükleri ile Kaiser-Meyer-Olkin (KMO) ve güvenirlik analizi için Cronbach's Alpha değerleri saptanıştır. Ancak hem verilerin normal dağılımına (Kolmogorov-Smirnov Test) hem de homojenliğine (Levene) ilişkin uygun testler yapıldığında, p değerlerinin 0,05'ten küçük olduğu tespit edilmiştir. Dolayısıyla parametrik test koşulları sağlanmadığı için parametrik olmayan testlerden bağımsız iki grubun karşılaştırılmasında Mann-Whitney U Testi ve birbirinden bağımsız ikiden fazla grubun karşılaştırılmasında Kruskal-Wallis H Testi ile araştırma sorusuna cevap aranmaya çalışılmıştır.

\section{BULGULAR}

Yapılan analizlerde öncelikle anketteki ölçeğin yapı geçerliğine ilişkin varimax rotasyonu ve temel bileşenler (principal components) yöntemi kullanılarak faktör analizi uygulanmıştır. Faktör analizinin uygulanabilirliği Bartlett testi, örneklem hacminin yeterliği ise Kaiser-Meyer-Olkin (KMO) değeri ile test edilmiştir. Ayrıca, ölçeklerin iç tutarlığına yönelik güvenirlik analizi için Cronbach's Alpha değerleri de Tablo 1'de sunulmuştur. 
Tablo 1. Turizmin Ekonomik, Sosyo-kültürel ve Çevresel Etkenlerine İlişkin İfadelerin Faktör Analizi

\begin{tabular}{|c|c|c|c|c|}
\hline Turizm Yenice'de; & 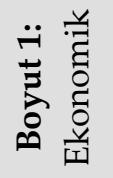 & 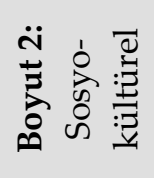 & 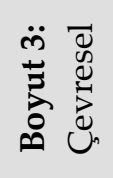 & $\overline{\mathrm{X}} / \mathrm{ss}$ \\
\hline 1- konukların daha fazla harcama yapmasını sağlayacaktır. & ,796 & & & $4,40 / 0,81$ \\
\hline 2- daha fazla yatırım yapılmasını sağlayacaktır. & ,648 & & & $4,24 / 0,80$ \\
\hline 3- devlet teşviklerinin artmasını sağlayacaktır. & 612 & & & $4,28 / 0,89$ \\
\hline 4- mal ve hizmetlerin fiyatlarını artıracaktır. & 856 & & & $4,35 / 0,79$ \\
\hline 5- istihdam olanaklarını artıracaktır. & ,782 & & & $4,16 / 0,78$ \\
\hline 6- ekonomik anlamda olumlu katkılar sağlayacaktır. & ,799 & & & $4,05 / 0,84$ \\
\hline 7- çiftçiler için hazır bir pazar sağlayacaktır. & 602 & & & $4,15 / 0,80$ \\
\hline $\begin{array}{l}\text { 8- yaşayanların turistlerle arkadaşlık geliştirmesini } \\
\text { sağlayacaktır. }\end{array}$ & & 811 & & $2,38 / 1,07$ \\
\hline $\begin{array}{l}\text { 9- yaşayanların turistlerle faydalı etkileşimler geliştirmesini } \\
\text { sağlayacaktır. }\end{array}$ & & 778 & & $2,59 / 1,16$ \\
\hline $\begin{array}{l}\text { 10- yaşayanların turistlerin bulunduğu bölgeleri ziyaret } \\
\text { etmekten zevk almalarını sağlayacaktır. }\end{array}$ & & 684 & & $2,56 / 1,31$ \\
\hline $\begin{array}{l}\text { 11- turistlerin kültürleri hakkında yerel halkın yeni bilgiler } \\
\text { öğrenmesini sağlayacaktır. }\end{array}$ & & ,737 & & $2,64 / 1,18$ \\
\hline 12- kültür alışverişini teşvik edecektir. & & ,545 & & $2,86 / 1,23$ \\
\hline 13- iş kollarını cazip hale getirecektir. & & ,489 & & $2,40 / 1,11$ \\
\hline $\begin{array}{l}\text { 14- insanlar arasındaki karşılıklı anlayışı iyi yönde } \\
\text { geliştirecektir. }\end{array}$ & &, 501 & & $2,56 / 1,20$ \\
\hline 15- yerel kültür hakkındaki farkındalığ geliştirecektir. & &, 523 & & $2,94 / 1,05$ \\
\hline 16- kamu hizmetlerinin iyileşmesini sağlayacaktır. & & ,701 & & $2,82 / 1,21$ \\
\hline $\begin{array}{l}\text { 17- ülkemizin imajında, uluslararası düzeyde olumlu bir } \\
\text { değişmeye neden olacaktır. }\end{array}$ & &, 517 & & $3,47 / 1,15$ \\
\hline 18- gelenek ve görenekleri koruyup geliştirecektir. & & ,751 & & $3,52 / 1,16$ \\
\hline 19- geleneksel ürünleri canlandıracaktır. & & ,836 & & $3,30 / 1,33$ \\
\hline $\begin{array}{l}\text { 20- yaşayanların yabancı dil öğrenmesine katkıda } \\
\text { bulunacaktır. }\end{array}$ & & ,809 & & $1,95 / 0,97$ \\
\hline $\begin{array}{l}\text { 21- yaşayanların eğitim seviyesinin yükselmesine katkıda } \\
\text { bulunacaktır. }\end{array}$ & & 701 & & $2,46 / 0,99$ \\
\hline 22- tarihi yapıların yenilenmesi için fırsat sağlayacaktır. & & & 631 & $3,40 / 1,42$ \\
\hline $\begin{array}{l}\text { 23- otel ve diğer turistik tesis inşaatları sebebiyle bölgedeki } \\
\text { doğal çevreyi tahrip edecektir. }\end{array}$ & & & ,706 & $3,27 / 1,25$ \\
\hline 24- doğal kaynakların korunması için fırsat sağlayacaktır. & & & 804 & $3,45 / 1,36$ \\
\hline 25- karayolu ağının iyileşmesine vesile olacaktır. & & & ,791 & $3,18 / 1,34$ \\
\hline 26- kamu hizmetlerini kaliteli hale getirecektir. & & & 861 & $2,96 / 1,32$ \\
\hline
\end{tabular}




\begin{tabular}{|c|c|c|c|c|}
\hline 27- ulaşım hizmetlerini geliştirecektir. & & & 494 & $2,94 / 1,38$ \\
\hline 28- kalabalıklaşmaya neden olacaktır. & & & 859 & $2,71 / 1,33$ \\
\hline 29- altyapının iyileştirilmesini sağlayacaktır. & & & ,426 & $2,76 / 1,30$ \\
\hline 30- çevre bilincinin artmasında önemli rol oynayacaktır. & & & 484 & $2,70 / 1,25$ \\
\hline $\begin{array}{l}\text { 31- çevre korunmasına yönelik yasal düzenlemelerin } \\
\text { yapılmasını sağlayacaktır. }\end{array}$ & & & 823 & $2,85 / 1,16$ \\
\hline 32- manzaranın bozulmasına neden olacaktır. & & & 831 & $2,46 / 1,55$ \\
\hline 33- gürültü kirliliğine neden olacaktır. & & & ,761 & $2,14 / 1,33$ \\
\hline 34- düzensiz kentleşmeye neden olacaktır. & & & ,719 & $2,65 / 1,50$ \\
\hline$\overline{\bar{X}} / \mathrm{ss}$ & $4,23 / 0,44$ & $2,75 / 0,73$ & $2,88 / 0,74$ & \\
\hline Özdeğerler (eigenvalues) & 10,087 & 6,694 & 4,479 & \\
\hline Varyansı açıklama oranı & 29,667 & 19,688 & 13,174 & \\
\hline Kümülatif varyans & 29,667 & 49,355 & 62,529 & \\
\hline Alt Boyut Güvenirliği (Cronbach's Alpha) & 0,801 & 0,824 & 0,813 & \\
\hline Genel Ölçek Güvenirliği (Cronbach's Alpha) & & 0,884 & & \\
\hline
\end{tabular}

Kaiser-Meyer-Olkin $(K M O)=0,748$

Bartlett testi: $\chi^{2}=21659,505 ; p=0,000$

Yerel halkın turizmin etkenleri konusundaki görüşlerini yansıtan 34 ifadeye ilişkin faktör analizi sonucunda, Bartlett testi 21,659 ve $p$ anlamlılık değeri $(p<0.00)$ bulunmuş olup, Kaiser-Meyer-Olkin (KMO) örneklem değeri 0,748 olarak tespit edilmiştir. Kalaycı'ya (2009) göre bu değerler faktör analizi uygulamak için yeterli seviyede kabul edilmektedir. Eroğlu (2005) de 350 ve üzerindeki veri sayısı için faktör ağırlığının 0,30 ve üzerinde olması gerektiğini belirttiğinden ve araştırmadaki ifadelere ilişkin tüm faktör yükleri belirtilen değerin üzerinde olduğundan faktör yükleri de kabul edilebilir seviyededir. Ayrıca hem alt boyutların hem de genel ölçek güvenilirliğinin değerleri de 0,70'in üzerinde olduğu için ölçeklerin iç tutarlılık düzeylerinin yeterli olduğu (Kayış, 2009) söylenebilir.

Tablo 2. Yerel Halkın Cinsiyetine Göre Turizmin Ekonomik, Sosyo-Kültürel ve Çevresel Boyutlarına Yönelik Düşüncelerinin Karşılaştırılması (Mann-Whitney U Testi)

\begin{tabular}{lllcccc}
\hline \multicolumn{1}{c}{ Boyutlar } & Cinsiyet & $\mathbf{N}$ & $\begin{array}{c}\text { Siralama } \\
\text { Değeri } \\
\text { Ortalamas1 }\end{array}$ & $\begin{array}{c}\text { Siralama } \\
\text { Değerleri } \\
\text { Toplamı }\end{array}$ & $\begin{array}{c}\text { Mann- } \\
\text { Whitney U }\end{array}$ & p \\
\hline Ekonomik & Erkek & 492 & 371,39 & 182724,00 & 39906,000 & $\mathbf{0 , 0 0 0 *}$ \\
\cline { 2 - 5 } & Kadın & 206 & 297,22 & 61227,00 & & \\
\hline $\begin{array}{l}\text { Sosyo- } \\
\text { Kültürel }\end{array}$ & Erkek & 492 & 349,48 & 171946,50 & 50668,500 & 0,998 \\
\cline { 2 - 5 } Çevresel & Kadın & 206 & 349,54 & 72004,50 & & \\
\cline { 2 - 5 } & Erkek & 492 & 389,25 & 191511,50 & 31118,500 & $\mathbf{0 , 0 0 0 *}$ \\
\hline
\end{tabular}

${ }^{*} p<0,05$ 
Yerel halkın cinsiyetlere göre turizmin (ekonomik, sosyo-kültürel ve çevresel) etkenlerine yönelik verdikleri cevaplar arasındaki anlamlı farklılığı belirleyebilmek için yapılan Mann-Whitney U testi sonuçları Tablo 2'de görülmektedir. Test sonuçlarına göre, erkek ve kadınların ekonomik ( $U=39906,0 ; p<0,05)$ ve çevresel $(U=31118,5 ; p<0,05)$ etkenler konusundaki görüşleri farklılık gösterirken, sosyo-kültürel ( $U=50668,5 ; p>0,05)$ etkenle ilgili görüşleri arasında anlamlı bir faklılık bulunamamıştır. Sıralama değeri ortalaması incelendiğinde ekonomik ve çevresel etkenler konusunda erkeklerin, kadınlara göre daha olumlu düşüncelere sahip olduğu söylenebilir. Dolayısıyla erkekler ilçenin turizme açılmasıyla bölgede ekonomik ve çevresel anlamda olumlu değişimlerin olacağını kadınlara oranla daha olumlu yordalamaktadırlar. Ancak her iki grubun da sosyo-kültürel etken hakkındaki görüşleri aynı seviyededir.

Tablo 3. Yerel Halkın Medeni Durumuna Göre Turizmin Ekonomik, Sosyo-Kültürel ve Çevresel Boyutlarına Yönelik Düşüncelerinin Karşılaştırılması (Mann-Whitney U Testi)

\begin{tabular}{|c|c|c|c|c|c|c|}
\hline Boyutlar & $\begin{array}{l}\text { Medeni } \\
\text { Durum }\end{array}$ & $\mathbf{N}$ & $\begin{array}{c}\text { Siralama } \\
\text { Değeri } \\
\text { Ortalaması }\end{array}$ & $\begin{array}{c}\text { Siralama } \\
\text { Değerleri } \\
\text { Toplamı }\end{array}$ & $\begin{array}{c}\text { Mann- } \\
\text { Whitney U }\end{array}$ & $\mathbf{p}$ \\
\hline \multirow[t]{2}{*}{ Ekonomik } & Evli & 457 & 378,32 & 172892,00 & 41898,000 & $0,000^{*}$ \\
\hline & Bekar & 241 & 294,85 & 71059,00 & & \\
\hline \multirow{2}{*}{$\begin{array}{l}\text { Sosyo- } \\
\text { Kültürel }\end{array}$} & Evli & 457 & 361,84 & 165361,00 & 49429,000 & $0,026^{*}$ \\
\hline & Bekar & 241 & 326,10 & 78590,00 & & \\
\hline \multirow[t]{2}{*}{ Çevresel } & Evli & 457 & 352,73 & 161198,50 & 53591,500 & 0,559 \\
\hline & Bekar & 241 & 343,37 & 82752,50 & & \\
\hline
\end{tabular}

${ }^{*} p<0,05$

Tablo 3'te yerel halkın medeni durumlarına göre turizmin (ekonomik, sosyokültürel ve çevresel) etkenlerine yönelik verdikleri cevapların farklılığına ilişkin yapılan Mann-Whitney $U$ testi sonuçlarına göre, ekonomik ( $U=41898,0 ; p<0,05)$ ve sosyo-kültürel $(\mathrm{U}=49429,0 ; \mathrm{p}<0,05)$ etkenler konusundaki evli ile bekar katılımcıların görüşleri farklılık gösterirken, çevresel (U=53591,5;p>0,05) etkenle ilgili görüşleri arasında anlamlı bir faklılık bulunamamıştır. Sıralama değeri ortalamalarında ekonomik ve sosyo-kültürel etkenler konusunda evlilerin, bekarlara göre daha olumlu düşüncelere sahip olduğu söylenebilir. Dolayısıyla evliler ilçenin turizme açılmasıyla bölgede ekonomik ve sosyo-kültürel açıdan olumlu değişimlerin olacağını bekarlara oranla daha olumlu değerlendirmektedir. Ancak her iki grubun da çevresel etken hakkındaki görüşleri aynı farklılık göstermemektedir. 
Tablo 4. Yerel Halkın Doğum Yerine Göre Turizmin Ekonomik, Sosyo-Kültürel ve Çevresel Boyutlarına Yönelik Düşüncelerinin Karşılaştırılması (Mann-Whitney U Testi)

\begin{tabular}{|c|c|c|c|c|c|c|}
\hline Boyutlar & $\begin{array}{c}\text { Doğum } \\
\text { Yeri }\end{array}$ & $\mathbf{N}$ & $\begin{array}{c}\text { Siralama } \\
\text { Değeri } \\
\text { Ortalaması } \\
\end{array}$ & $\begin{array}{c}\text { Siralama } \\
\text { Değerleri } \\
\text { Toplamı } \\
\end{array}$ & $\begin{array}{c}\text { Mann- } \\
\text { Whitney U }\end{array}$ & $\mathrm{p}$ \\
\hline \multirow[t]{2}{*}{ Ekonomik } & Yenice & 637 & 348,70 & 222124,00 & 18921,000 & 0,734 \\
\hline & Yenice D1şı & 61 & 357,82 & 21827,00 & & \\
\hline \multirow{2}{*}{$\begin{array}{l}\text { Sosyo- } \\
\text { Kültürel }\end{array}$} & Yenice & 637 & 345,18 & 219881,50 & 16678,500 & 0,067 \\
\hline & Yenice D1ş1 & 61 & 394,58 & 24069,50 & & \\
\hline \multirow[t]{2}{*}{ Çevresel } & Yenice & 637 & 347,93 & 221634,50 & 18431,500 & 0,507 \\
\hline & Yenice D1ş1 & 61 & 365,84 & 22316,50 & & \\
\hline
\end{tabular}

Turizmin ekonomik, sosyo-kültürel ve çevresel etkenleri ile ilçede yaşayan yerel halkın doğum yerine göre yapılan farklılık analizi Tablo 4'te yer almaktadır. İlgili tabloya göre hem Yenice'de hem de Yenice dişında doğum yerine sahip olan ve ankete katılan bireylerin görüşleri turizmin ekonomik ( $U=18921,0 ; p>0,05)$, sosyo-kültürel $(\mathrm{U}=16678,5 ; \mathrm{p}>0,05) \quad$ ve çevresel $(\mathrm{U}=18431,5 ; \mathrm{p}>0,05)$ etkenlerine göre farklılık göstermemektedir. Bu sonuçlar paralelinde turizmin tüm etkenlerine yönelik görüşler sıralama değeri ortalaması dikkate alındığında Yenice veya Yenice dışı doğum yerine sahip olsalar da tüm katılımcılarda birbirlerine yakın seviyededir.

Tablo 5. Yerel Halkın Yaşına Göre Turizmin Ekonomik, Sosyo-Kültürel ve Çevresel Boyutlarına Yönelik Düşüncelerinin Karşılaştırılması (Kruskal-Wallis H Testi)

\begin{tabular}{llccccc}
\hline Boyutlar & $\begin{array}{c}\mathbf{1 8 - 2 7} \text { yaş } \\
(\mathbf{n} / \overline{\mathrm{X}})\end{array}$ & $\begin{array}{c}\mathbf{2 8 - 3 7} \text { yaş } \\
(\mathbf{n} / \overline{\mathrm{X}})\end{array}$ & $\begin{array}{c}\mathbf{3 8 - 4 7} \text { yaş } \\
(\mathbf{n} / \overline{\mathrm{X}})\end{array}$ & $\begin{array}{c}\text { 48 yaş ve } \\
\text { üzeri } \\
(\mathbf{n} / \overline{\mathrm{X}})\end{array}$ & $\begin{array}{c}\text { Chi- } \\
\text { Square }\end{array}$ & $\mathbf{p}$ \\
\hline Ekonomik & $232 / 273,75$ & $309 / 400,65$ & $73 / 309,12$ & $84 / 405,65$ & 62,791 & $\mathbf{0 , 0 0 0}$ \\
\hline Sosyo-Kültürel & $232 / 378,05$ & $309 / 312,44$ & $73 / 328,21$ & $84 / 425,48$ & 27,932 & $\mathbf{0 , 0 0 0}$ \\
\hline Çevresel & $232 / 423,18$ & $309 / 280,07$ & $73 / 291,36$ & $84 / 451,93$ & 95,806 & $\mathbf{0 , 0 0 0}$ \\
\hline${ }^{*} p<0,05$ & & & & & &
\end{tabular}

Yerel halkın yaşları itibariyle turizmin ekonomik, sosyo-kültürel ve çevresel etkenleri değerlendirildiğinde tüm etkenlerle yaş grupları arasında farklılık tespit edilmiştir. Tablo 5'e göre ekonomik etken ile yaş grupları arasındaki farklılıkla $\left(X^{2}=62,791 ; p<0,05\right)$ ilgili olarak 28-37 yaş grubu ve 48 yaş ve üzerindeki katılımcıların diğer yaş gruplarından daha olumlu düzeyde olduğu söylenebilir. Bu etkenle ilgili en olumsuz düşünen yaş grubu 18-27 olarak belirlenmiştir. Sosyo-kültürel etken hakkında ise en olumsuz görüşler 28-37 yaş grubunda belirlenirken, 48 yaş ve üzerindeki katılımcıların en olumlu görüşe sahip olduğu belirtilebilir. Çevresel etken hakkında yine en olumlu görüşler 48 yaş ve üzerindeki katılımcılar tarafından verilirken, 28-37 yaş grubunun bu konuda turizmin olumsuz etkileri olacağını düşündükleri söylenebilir. Tüm etkenler için 
48 yaş grubu ve üzerindekilerin turizm hakkında en olumlu görüşlere sahip olduğu tespit edilmiş olup, farklılığın kaynağını belirlemek amacıyla her grubu ikili olarak karşılaştırarak yapılan Mann-Whitney U Testi sonucunda da tüm etkenler için 18-27 yaş grubuyla 48 yaş üzerindeki grup arasında farklılıkların gerçekleştiği belirlenmiştir.

Tablo 6. Yerel Halkın Eğitim Durumuna Göre Turizmin Ekonomik, Sosyo-Kültürel ve Çevresel Boyutlarına Yönelik Düşüncelerinin Karşılaştırılması (Kruskal-Wallis H Testi)

\begin{tabular}{lccccc}
\hline Boyutlar & $\begin{array}{c}\text { İlköğretim } \\
(\mathbf{n} / \overline{\mathrm{X}})\end{array}$ & $\begin{array}{c}\text { Lise } \\
(\mathbf{n} / \overline{\mathrm{X}})\end{array}$ & $\begin{array}{c}\text { Üniversite } \\
(\mathbf{n} / \overline{\mathrm{X}})\end{array}$ & $\begin{array}{c}\text { Chi- } \\
\text { Square }\end{array}$ & $\mathbf{p}$ \\
\hline Ekonomik & $157 / 369,68$ & $473 / 348,61$ & $68 / 309,08$ & 4,365 & 0,113 \\
\hline Sosyo-Kültürel & $157 / 389,11$ & $473 / 327,04$ & $68 / 414,25$ & 19,010 & $\mathbf{0 , 0 0 0}$ \\
\hline Çevresel & $157 / 262,07$ & $473 / 372,25$ & $68 / 393,11$ & 38,905 & $\mathbf{0 , 0 0 0}$ \\
\hline${ }^{*} p<0,05$ & & & &
\end{tabular}

Yerel halkın eğitim durumuna göre turizmin ekonomik, sosyo-kültürel ve çevresel etkenlerinin değerlendirildiği Tablo 6'da sosyo-kültürel $\left(X^{2}=19,010 ; p<0,05\right)$ ve çevresel $\left(X^{2}=38,905 ; p<0,05\right)$ etkenlerde farklllık söz konusuyken, ekonomik $\left(X^{2}=4,365 ; p>0,05\right)$ etkenle ilgili farklılık belirlenememiştir. Turizmin hem sosyo-kültürel hem de çevresel etkenlerindeki farklılı̆̆ın kaynağını belirlemek amacıyla her grubu ikili olarak karşılaştırarak yapılan Mann-Whitney U Testi sonucunda; sosyo-kültürel etkende üniversite mezunları ile lise mezunları arasında, çevresel etken de ise üniversite mezunları ile ilköğretim mezunları arasında ilgili farklılıkların söz konusu olduğu söylenebilir.

Tablo 7. Yerel Halkın İlçedeki Yaşam Süresine Göre Turizmin Ekonomik, Sosyo-Kültürel ve Çevresel Boyutlarına Yönelik Düşüncelerinin Karşılaştırılması (Kruskal-Wallis H Testi)

\begin{tabular}{lccccc}
\hline Boyutlar & $\begin{array}{c}\mathbf{1 0} \text { yıl ve daha az } \\
(\mathbf{n} / \overline{\mathrm{X}})\end{array}$ & $\begin{array}{c}\mathbf{1 1 - 2 0} \mathbf{y 1} \\
(\mathbf{n} / \overline{\mathrm{X}})\end{array}$ & $\begin{array}{c}\mathbf{2 1} \text { yıl ve üzeri } \\
(\mathbf{n} / \overline{\mathrm{X}})\end{array}$ & $\begin{array}{c}\text { Chi- } \\
\text { Square }\end{array}$ & $\mathbf{p}$ \\
\hline Ekonomik & $65 / 353,52$ & $195 / 294,18$ & $438 / 373,53$ & 21,171 & $\mathbf{0 , 0 0 0}$ \\
\hline Sosyo-Kültürel & $65 / 146,53$ & $195 / 392,44$ & $438 / 360,51$ & 76,296 & $\mathbf{0 , 0 0 0}$ \\
\hline Çevresel & $65 / 274,47$ & $195 / 420,10$ & $438 / 329,20$ & 37,518 & $\mathbf{0 , 0 0 0}$ \\
\hline${ }^{*} p<0,05$ & & & & &
\end{tabular}

Tablo 7'de yerel halkın ilçedeki yaşam süreleri dikkate alınarak turizmin ekonomik, sosyo-kültürel ve çevresel etkenlerine verdikleri cevaplar arasındaki farklılıklar yer almaktadır $\left(X^{2}=21,171 ; 76,296 ; 37,518 ; p<0,05\right)$. Farklılığın kaynağı için yapılan MannWhitney U Testinde ekonomik etkende 11-20 yıl ile 21 yıl ve üzeri grup arasında, sosyokültürel ve çevresel etkenlerde ise 10 yıl ve daha az grup ile 11-20 yıl ve 21 yıl ve üzeri gruplar arasında saptanmıştır. 
Tablo 8. Yerel Halkın Gelirine Göre Turizmin Ekonomik, Sosyo-Kültürel ve Çevresel Boyutlarına Yönelik Düşüncelerinin Karşılaştırılması (Kruskal-Wallis H Testi)

\begin{tabular}{lcccccc}
\hline Boyutlar & $\begin{array}{c}\text { 1000TL ve } \\
\text { daha az } \\
(\mathbf{n} / \overline{\mathrm{X}})\end{array}$ & $\begin{array}{c}\mathbf{1 0 0 1 - 2 0 0 0 T L} \\
(\mathbf{n} / \overline{\mathrm{X}})\end{array}$ & $\begin{array}{c}\mathbf{2 0 0 1 - 3 0 0 0 T L} \\
(\mathbf{n} / \overline{\mathrm{X}})\end{array}$ & $\begin{array}{c}\text { 3001TL ve } \\
\text { üzeri } \\
(\mathbf{n} / \overline{\mathrm{X}})\end{array}$ & $\begin{array}{c}\text { Chi- } \\
\text { Square }\end{array}$ & p \\
\hline Ekonomik & $206 / 343,95$ & $329 / 388,63$ & $105 / 240,54$ & $58 / 344,52$ & 43,748 & $\mathbf{0 , 0 0 0}$ \\
\hline Sosyo-Kültürel & $206 / 317,45$ & $329 / 365,64$ & $105 / 318,43$ & $58 / 428,02$ & 18,669 & $\mathbf{0 , 0 0 0}$ \\
\hline Çevresel & $206 / 335,03$ & $329 / 343,27$ & $105 / 383,03$ & $58 / 375,54$ & 5,271 & 0,153 \\
\hline
\end{tabular}

${ }^{*} p<0,05$

Gelirlerine göre yerel halkın turizm hakkındaki ekonomik, sosyo-kültürel ve çevresel etnelere verdikleri cevapların değerlendirildiği Tablo 8'de çevresel etken $\left(X^{2}=5,271 ; p>0,05\right)$ hariç diğer etmenlerde anlamlı farklılık $\left(X^{2}=43,748 ; 18,669 ; p<0,05\right)$ bulunmuştur. Mann-Whitney U Testi ile yapılan gruplar arasındaki farklılığı incelenmiş olup, ekonomik etkende 1000TL ve daha az geliri olan katılımcilar ile 1001-2000TL ve 2001-3000TL geliri olan katılımcilar arasında, ek olarak 1001-2000TL ile 2001-3000TL geliri olan katılımcilar arasında ve 2001-3000TL ile 3001TL ve üzeri geliri olan katılımcilar arasında tespit edilmiştir. Sosyo-kültürel etkende 1000TL ve daha az geliri olan katılımcılar ile 1001-2000TL geliri olan katılımcilar arasında, ilaveten 1001-2000TL ve 20013000TL geliri olan katılımclar ile 3001TL ve üzeri geliri olan katılımcılar arasında farklılı̆̆ın kaynă̆ı saptanmıştır.

Tablo 9. Yerel Halkın Mesleklerine Göre Turizmin Ekonomik, Sosyo-Kültürel ve Çevresel Boyutlarına Yönelik Düşüncelerinin Karşılaştırılması (Kruskal-Wallis H Testi)

\begin{tabular}{lccccc}
\hline Boyutlar & $\begin{array}{c}\text { Özel Sektör } \\
(\mathbf{n} / \overline{\mathrm{X}})\end{array}$ & $\begin{array}{c}\text { Serbest Meslek } \\
(\mathbf{n} / \overline{\mathrm{X}})\end{array}$ & $\begin{array}{c}\text { Kamu Görevlisi } \\
(\mathbf{n} / \overline{\mathrm{X}})\end{array}$ & $\begin{array}{c}\text { Chi- } \\
\text { Square }\end{array}$ & $\mathbf{p}$ \\
\hline Ekonomik & $457 / 318,27$ & $70 / 312,49$ & $171 / 448,12$ & 54,868 & $\mathbf{0 , 0 0 0}$ \\
\hline Sosyo-Kültürel & $457 / 341,16$ & $70 / 380,19$ & $171 / 359,24$ & 2,813 & 0,245 \\
\hline Çevresel & $457 / 339,10$ & $70 / 316,31$ & $171 / 390,87$ & 10,360 & $\mathbf{0 , 0 0 6}$ \\
\hline
\end{tabular}

${ }^{*} p<0,05$

Tablo 9'da yerel halkın mesleklerine göre turizmin ekonomik, sosyo-kültürel ve çevresel etkenlere yönelik düşüncelerinin karşılaştırılması için yapılan Kruskal-Wallis H Testi sonuçları yer almaktadır. Test sonucunda ekonomik ve çevresel etkenlerde farklilıklar $\left(X^{2}=54,868 ; 10,360 ; \quad p<0,05\right)$ bulunurken, sosyo-kültürel etkende fark bulunamamıştır $\left(X^{2}=2,813 ; p>0,05\right)$. Gruplar arasındaki farklılık tespitinde yapılan MannWhitney U Testi sonucunda ekonomik etkende; katılımcılardan özel sektör ve serbest meslek çalışanları ile kamu görevlileri arasında, çevresel etkende ise özel sektör ile kamu görevlileri arasında farklılığın kaynağı tespit edilmiştir. 


\section{SONUÇ VE ÖNERILER}

Turizm faaliyetlerinin her anlamda geliştirilebilmesi ve sürdürülebilir olabilmesi, sektördeki işletmeler, çalışanlar ve turistler kadar yerel halkın katılımıyla da mümkün olmaktadır. Bu sebeple yerel halkın bölgelerindeki turizm faaliyetlerine yönelik görülerinin alınması gerekmektedir. Aksi halde yerel halkın turizme bakış açıları değerlendirilmeden bölgenin turizm faaliyetlerine açılması turizmin gelişimine yönelik programların ve çalışmaların uygulamada başarısız ve etkisiz olabileceğini göstermektedir (Harrison, 1992; Sırakaya vd., 2002; Gürsoy vd., 2002; Akova, 2006; Tayfun ve Kılıçlar, 2004).

Bu kapsamda Karabük ili Yenice ilçesinde yaşayan yerel halkın turizm faaliyetlerinin ilçeye yönelik ekonomik, sosyo-kültürel ve çevresel etkileri hakkındaki görüşleri alınmak suretiyle, bölgenin turizme olan ilgisi, bilgisi ve hazır bulunuşluk düzeyine ilişkin tespitlere ulaşılmaya çalışılmıştır. Elde edilen sonuçlar bağlamında; yerel halkın cinsiyetine yapılan farklılık testinde ekonomik ve çevresel etkenlerde erkeklerin kadınlara göre daha olumlu görüşe sahip oldukları belirlenmiştir. Dolayısıyla kadın katılımcıların turizm faaliyetlerine erkekler kadar olumlu bakmadıkları söylenebilir. Bu durum kadınların turizm faaliyetleriyle birlikte ilçenin ekonomik ve çevresel olarak olumsuz etkilenebileceğine olan inançları ve kaygıları ile açıklanabilir.

Evli ve bekarlar arasında belirlenen farklılıklar ekonomik ve sosyo-kültürel etkenlerde ortaya çıkmıştır. Çalışmaya görüş bildiren evliler bekarlara göre turizm faaliyetlerinin ekonomik ve sosyo-kültürel anlamdaki etkilerine daha olumlu görüş bildirmişlerdir. Bu tespit, Ayaz vd. (2009) çalışmasının tam tersi bir sonucu ortaya çıkarmıştır. Dolayısıyla Yenice'deki yerel halk içerisinde evlilerin turizm faaliyetlerine yönelik olumlu bakış açıları, bilgileri ve tecrübelerinin bekarlara göre fazla olduğu söylenebilir. Aynı durum katılımcıların yaşlarına göre yapılan farklılık analizinde de kendini göstermektedir. Yaşlarına göre de katılımcıların tüm etkenlere yönelik görüşleri arasında farklılıklar belirlenmiş olup, özellikle ilçede yaşayan orta yaş üzerine denk gelen grubun turizm faaliyetlerine her etken boyutunda daha olumlu görüş bildirmeleri, ileri yaş grubundaki katılımcıların gençlere göre turizm hakkında daha pozitif düşündüklerini ortaya çıkarmaktadır.

Eğitim durumları açısından katılımcıların turizm faaliyetlerinin etkenlerine göre görüş farklılıkları incelendiğinde; sosyo-kültürel ve çevresel etkenlerde farklılığın olduğu saptanmıştır. Öyle ki, her iki etkende de üniversite mezunları daha olumlu görüşler bildirmişlerdir. Bu sonuç üniversite mezunu katılımcıların turizm faaliyetleri konusunda bilgi düzeylerinin diğer eğitim durumdaki katılımcılara göre daha yüksek olması ile ilişkilendirilebilir. Ayrıca belirlenen bu sonuç Ayaz vd. (2009) çalışması ile de paralellik göstermektedir. Yenice'deki yaşam süreleri itibariyle ekonomik etkende 21 yıl ve üzerinde ilçede yaşayanlar daha olumlu görüşlere sahipken, sosyo-kültürel ve çevresel etkenlerde 11-20 yıl arasında ilçede yaşayanların görüşleri daha olumlu düzeyde gerçekleşmiştir. 
Tayfun (2002) çalışmasında da ikamet yerinin önemi yerel halkın turizme bakış açısında vurgulanan önemli bir husus olarak kabul edilmiştir. Genel bir değerlendirme ile ilçede 10 yılın üzerinde yaşayan katılımcıların turizm faaliyetlerine yönelik düşünceleri daha olumlu seviyede olup, bu bulgu ilçeyi daha iyi tanıyanların turizm faaliyetlerinin ilçeye olan katkıları hakkında farkındalıklarının daha gelişmiş olduğu şeklinde yorumlanabilir.

Yerel halkın gelirlerine göre yapılan farklılık analizinde ekonomik ve sosyokültürel etkenlerde farklılık tespit edilmiştir. Gelir grubu 1001-2000TL arasında olanlar ekonomik etkende en olumlu görüşleri belirtirken, 3001TL ve üzerinde gelire sahip olanlar sosyo-kültürel etkende en olumlu görüşleri sergilemişlerdir. Bu durum gelir seviyesi yüksek olanların turizm faaliyetlerinin sosyo-kültürel yansımalarına daha fazla odaklanmaları bunun yanında 1001-2000TL gelire sahip olanların ise daha çok ekonomik açıdan turizm faaliyetlerini değerlendiriyor olmalarıyla açıklanabilir. Son olarak mesleklere göre yapılan farklılık testinde; ekonomik ve çevresel etkenlerde farklılıklar belirlenmiş olup, her iki etkende de kamu görevlilerinin turizm faaliyetlerine diğer meslek gruplarından daha olumlu görüş bildirdikleri tespit edilmiştir. Bu durum tıpkı eğitim de olduğu gibi kamu görevlilerinin bilgi bilinç düzeylerinin daha yüksek olması paralelinde turizm faaliyetlerine daha olumlu bakış açısına sahip olmalarıyla değerlendirilebilir.

Çalışmadan elde edilen bu çarpıcı sonuçlar konuyla ilgili bazı önerileri de sunmayı gerekli kılmaktadır. Bu noktada turizm faaliyetleri ile bilgilendirme çalışmalarının bölge halkının turizmi algılayabilmesi, ekonomik, sosyo-kültürel ve çevresel etkenler ölçeğinde olumlu ve olumsuz etkilerini daha doğru analiz etmelerinde faydalı olabilecektir. Her bölge için turizm faaliyetleri başlamadan önce yerel halkın görüşleri değerlendirilmeli, olumsuzluklar söz konusu ise turizm eğitimleriyle desteklendikten, olumsuz düşünceler giderildikten sonra turizm faaliyetlerinin gündeme alınması amaçlanmalıdır. Tayfun ve Kılıçlar (2004) çalışmalarında bu paralelde turizm faaliyetlerinin bölge altyapısına ve sosyal faaliyetlerine olan katkılarına vurgu yapmışlardır. Kaldı ki Akova (2006) araştırmasının sonuçlarında turistlerle temas kuranların sektörün ekonomiye olan katkıları konusunda bilgi sahibi olduklarını, yerel halkın eğitim seviyeleri artıkça da turizmin hayat standartlarına katkı sağlayacağını düşündükleri ve yaş grubu arttıkça yine turizm hakkındaki olumlu düşüncelerin artış gösterdiğini vurgulamıştır. Bu bilgiler 1şığında elde edilen sonuçların bu çalışma ile örtüştüğü söylenebilir.

Turizmin bir bölgede geliştirilebilmesi amacıyla yerel halkın görüşlerinin alınması yönünde yapılan bu ve benzeri çalışmalar bir kez daha göstermiştir ki, turizm planlayıcıları, mesleki kuruluşlar, uzmanlar, akademisyenler, yerel yönetimler, turizm işletme sahipleri vb. kitlelere önemli fikirler sunmaktadır. Dolayısıyla her bölgenin turizm faaliyetlerine açlmadan önce yerel halkın görüşleri ekseninde değerlendirmelerin yapılacak olması ilerde bölgesel ve hatta ulusal-uluslararası anlamda karşılaşılabilecek sorunların çözümüne destek olabilecek en temel husustur. Bu benzeri konuların ilgili kurum ve kuruluşlar tarafından desteklenerek, turizm faaliyetlerinin sistemli bir biçimde 
hayata geçirilmesi her şeyden daha çok turizmle birebir iç içe olanlara büyük faydalar sağlayabilecektir. Ayrıca çalışmanın Yenice ilçesindeki turizm çalışmalarına yönelik halkın görüşlerine yer veren bir çalışma olması, ilçenin adının turizm faaliyetleri açısından duyurulması, ilçedeki turistik değerlerin yansıtılması, bölgedeki turizm olanaklarına dikkat çekmesi ve ilçenin korunan alanlar kapsamında önemli bir yere sahip olduğunun vurgulanması çerçevesinde hem teorik hem de pratik olarak alana önemli katkıları olduğu söylenebilir.

\section{TEŞEKKÜR}

Bu çalışma KBÜ-BAP-14/2-DS-069 No'lu “Korunan Alanların Turizme Açılmasına İlişkin Yerel Halkın Görüşleri (Yenice Örneği)” başlıklı projeden üretilmiş olup, Karabük Üniversitesi Bilimsel Araştırma Proje Koordinatörlüğü tarafından desteklenmiştir.

\section{KAYNAKÇA}

Akova, O.(2006). Yerel Halkın Turizmin Etkilerini Algılamalarına ve Tutumlarına Yönelik Bir Araştırma, Sakarya Üniversitesi Sosyal Bilimler Dergisi Akademik İncelemeler, 2(1),77-109.

Akten, S., Gül, A., Akten, M. (2009). Korunan Doğal Alanların Katılımcı Yönetim Planında Ziyaretçi Etki Yönetimi Yaklaşımı, International Davraz Congress on Social and Economic Issuess Shaping The World's Future: New Global Dialogue, 24-27 September 2009, Isparta.

Alaeddinoğlu, F. (2007). "Van Halkının Turisti ve Turizmi Alg̨lama Şekli”, Coğrafi Bilimler Dergisi, 5 (1), 2007, 1-16.

Alptekin, C.Ü., İmal, B., Öner, N. (2010). Ülkemizde Doğal Korunan Alanlar ve Milli Parklarda Alınabilecek Silvikültürel Önlemler, III. Ulusal Karadeniz Ormancılık Kongresi, 20-22 Mayıs 2010, Artvin.

Andriotis, K. \& Vaughan, R.D. (2003). Urban Residents' Attitudes Toward Tourism Development: The Case Of Crete. Journal of Travel Research, 42 (2), 172- 184.

Ayaz, N., Artuğer, S. ve Türkmen, F. (2009). Tarihi Zela (Zile) İlçesindeki Halkın Turizme Bakış Açılarını Belirlemeye Yönelik Bir Alan Araştırması, Gazi Üniversitesi Ticaret ve Turizm Eğitim Fakültesi Dergisi, 2, 103-124.

Butler, R. ,W. (1980) “The Concept Of A Tourist Area Cycle Of Evolution: Implication For The Management Of Resources", Canadian Geographer, XXIV: p: 5-12.

Cengiz, E ve Kırkbir, F. (2007). Yerel Halk Tarafindan Algılanan Toplam Turizm Etkisi İle Turizm Desteği Arasındaki İlişkiye Yönelik Yapısal Bir Model Önerisi, Sosyal Bilimler Dergisi, s:19-37.

Dönmez, Y. (2013). Seyfe Gölü Tabiatı Koruma Alanının Biyosfer Rezervi Olarak Planlanması, Ankara Üniversitesi, Fen Bilimleri Enstitüsü, Doktora Tezi, Ankara.

Getz, D. (1994) "Residents' Attitudes Toward Tourism: A Longitudinal Study in Spey Valley, Scotland", Tourism Management, 15(4), 247-258.

Gümüş, S. ve Özüpekçe, N. (2009). "Foça'da Turizmin Ekonomik, Sosyal, Kültürel ve Çevresel Etkilerine Yönelik Yerel Halkın Görüşleri", Uluslar arası İnsan Bilimleri Dergisi, Cilt:6, $\quad$ Sayı:2. 
Güneş, G. (2011). Korunan Alanların Yönetiminde Yeni Bir Yaklaşım: Katılımcı Yönetim Planları, Ekonomi Bilimleri Dergisi. Cilt 3, No 1.

Gürsoy, D., Jurowski, C. ve Uysal, M. (2002). Resident Attitudes A Strucyural Modeling Approach, Annals of Tourism Research, 29(1), 79-105.

Harrison, D. (1992). Tourism in Less developed Countries, Belhaven: London.

Hepcan Ş. (1995). Ekoloji Yönünden Önemli Biyotopların Haritalanması ve Kentsel Ekosistemlerde Doğa Koruma Açısından Önemi, Ekoloji Dergisi, Ocak-Mart, Sayı 14, 47-50.

Hepcan, Ş., Güney, A. (1996). Koruma Alanlarında Yeni Yönetim Kategorileri ve Önemi. Ekoloji Dergisi. Temmuz-Ağustos-Eylül, Sayı: 30, 6-8.

Kalaycı, Ş. (2009). SPSS uygulamalı çok deği̧şkenli istatistik teknikleri, Ankara: Asil Yayın Dağıtım.

Kayış, A. (2009). Güvenirlik Analizi. Şeref Kalaycı (Editör), SPSS Uygulamalı Çok Değişkenli İstatistik Teknikleri. Ankara: Asil Yayın Dağıtım.

Kozak, N., Kozak, M. A. ve Kozak M. (2010). Genel Turizm - Ilkeler Kavramlar, Detay Yayınc1lı: Ankara.

Liu, J. C., Sheldon, P. ve Var, T. (1987). "Resident Perceptions of The Environmental Impact of Tourism", Annals of Tourism Research, 14, 17-37.

McCool, S. F. ve Martin, S. T. (1994). "Community Attachment and Attitudes Toward Tourism Development", Journal of Travel Research, 32(3), 29-34.

Murphy, P.E. (1983). "Perceptions and Attitudes of Decision-Making Groups in Tourism Centers", Journal of Travel Research, 21(3), 8-12.

Özdamar, K. (2001). Spss ile Biyoistatistik (4. basım). Eskişehir: Kaan Kitabevi.

Perdue, R.R., Long, P. T. ve Allen, L. (1990). "Rural Resident Tourism Perceptions and Attitudes by Community Level of Tourism", Journal of Travel Research, 28(3), 3- 9.

Sarıçam, Y, S. (2007). İzmir Il Bütününde Biyosfer Rezerv Alanları ve Saptanması Üzerine Araştırmalar "Karaburun Yarımadası Örneği". Ege Üniversitesi, Fen Bilimleri Enstitüsü, Doktora Tezi, İzmir.

Sirakaya, E., Teye, V. ve Sönmez, S. (2002). Understanding Residents' Support for Development in the Central Region of Ghana, Journal of Travel Research, 41, 57-67.

Tayfun, A. (2002). Turist Yerli Halk Etkileşimi Üzerine Bir Araştırma, $\quad$ Gazi Üniversitesi Ticaret ve Turizm Eğitim Fakültesi Dergisi, 1, 1-11.

Tayfun, A. ve Kılıçlar, A. (2004). Turizmin Sosyal Etkileri ve Yerli Halkın Turiste Bakışı, Gazi Üniversitesi Ticaret ve Turizm Eğitim Fakültesi Dergisi, 1, 1-17.

Teye, V., Sönmez, S. F. ve Sirakaya, E. (2002). Residents' Attitudes Toward Tourism Development, Annals of Tourism Research, 29(3), 668-688. 
Türker N., Öztürk S., ve Alaeddinoglu F. (2013). Local Community Involvement in Tourism in Yenice County (YC),Karabuk, Turkey, Communities as a Part of Sustainable Rural Tourism - Success Factor or Inevitable Burden? Proceedings of the Community Tourism Conference, 10th 11th September 2013 in Kotka, Finland.

Türker N. ve Çetinkaya A. (2009). Batı Karadeniz Bölümü Ekoturizm Potansiyeli, ISBN: 978- 60589395-0-9, Ankara: Detay Yayıncilı.

Yüksek, T., Cengiz, T., Yüksek, F. (2008). Doğal Alanlarda Festival Etkinliklerinin Koruma-Kullanma Açısından Değerlendirilmesi: Kafkasör Kültür, Sanat ve Turizm Festivali Örneği. Ekoloji Dergisi. 17 (67): 37-45. 